\title{
Labour market flexibility: wage relativities under the Labour Relations Act 1987
}

\author{
Walter Grills*
}

The abolition of compulsory arbitration means that bargaining power will be essential to achieve superior settlements. Workers will be attracted to stronger unions and there will be a change in union structure. The dismantling of the welfare state will mean that workers will come to depend on union bargaining power for protection. The objects of unions and the subject matter of bargaining are no longer restricted, and the union can insist that the employer provide security which was formerly provided by the state. Restructuring the union movement as promoted by the Labour Relations Act will not in the long run lead to greater wage flexibility. Unions will remain occupationally based, and will be parties to occupationally-based awards which do not accommodate the economic circumstances of individual industries or employers. There will be a smaller number of more powerful unions holding the national award structure together through bargaining power, rather than by the force of the Arbitration Commission's reasoning.

\section{Compulsory arbitration and the welfare state}

For a major part of the century New Zealand has operated a compulsory arbitration/union membership system. The basic design developed from the 1894 Industrial Conciliation and Arbitration Act. The Act was part of a series of measures to regulate New Zealand industry and included the early Factories, Mines, and Shops and Offices Acts. The provisions of the compulsory arbitration system regulated the standards for minimum wages and conditions throughout the range of industries in New Zealand. Welfare legislation ensured that minimum standards of health, education and welfare were maintained. In a parallel way, the industrial relations system was a subsystem within the overall system which comprised the welfare state. Minimum standards of wages and conditions were guaranteed through a compulsory arbitration system. Yet the union movement seemed curiously unaware of their dependence upon the regulations of the welfare state.

Following periods where successive governments deemed it necessary for unions and employers to limit wage increases, or freeze wage negotiations, the union movement sought a "return to free wage bargaining". Free wage bargaining meant that unions should be free to drive home wage settlements by striking either in breach of the law or in breach 
of the spirit of the law upon which the compulsory arbitration system was founded. There was no reciprocity for employers who remained yoked to the compulsory arbitration system, but in seeking freedom for the union movement to bargain without restriction, unions overlooked some of the logical accompaniments to free collective bargaining. If the union is free to bargain, so must the employer be free to bargain. If a union is free to strike over a collective agreement, it follows that the employer should also have unlimited freedom to bargain. The full range of freedoms include a freedom to refuse to go to arbitration, to refuse to enter into collective bargaining, to refuse to accept the union as a legitimate bargaining agent, to refuse the application of an industry-based award to the employers particular enterprise, and to refuse to bargain with or employ union labour.

\section{The deregulation of the labour market}

In contrast to being part of a package to regulate industry, the Labour Relations Act is part of a package to deregulate New Zealand industry. A critical aspect of the Act is that compulsory arbitration is no longer provided for. The right to strike over new or renewed awards is enshrined in the new legislation. There is no longer direct legislative intervention into the bargaining arena. Unions are free to claim any quantum of wages, and any particular conditions of employment. But the unions can no longer compel the employers to go to arbitration. Settlements depend on bargaining power. Bargaining power in turn depends on the state of the economy, and at present the balance is against the union movement. Weaker unions may shortly experience the bitter taste of "free collective bargaining" and regret the passing of the compulsory arbitration system.

However, the Labour Relations Act only in part deregulates the labour market, and some conservative ideologues amongst employer ranks are critical of the Act because it does not represent the full deregulation of the labour market. Compulsory unionism, union recognition and industry-wide bargaining rights, which were all secured by the compulsory arbitration legislation, remain less secure, but nevertheless important features of the Labour Relations Act. However, deregulation, like free collective bargaining, is a term which is presently being used with a profound sense of confusion. It would be trite to recount the history of the monopoly and price-fixing on the product market, but it is necessary to remind free marketeers that monopoly is no less a goal of the players on the labour market. Governments intervene in labour markets because the natural object of the bargainers in the labour market is the same objective as those on the product market market dominance and monopoly. The history of the laissez-faire approach to the labour market reveals that the tactics of employers and unions alike can be not only unfair, but applied with such single-minded, self-interested ferocity that national interest is placed in jeopardy. The balance of bargaining power will not always remain in the employers' favour, and an employer concern for regulating the labour market is likely to be reborn.

\section{Freedom to strike and wage relativity}

The central regulatory mechanism under the former compulsory arbitration/union system was the prohibition of strikes and the requirement of arbitration. Strikes were illegal when a dispute of interest was being processed within the conciliation and arbitration procedures. Under the former Act disputes of right were to be determined by arbitration within disputes committees, and personal grievances against the employer (mainly unjustified dismissals) were settled within grievances committees. Strikes were also prohibited over issues which came within the jurisdiction of disputes and personal grievance procedures. The design of the compulsory arbitration system was based on the 
assumption that industrial disputes were best decided by reason of the court rather than the bargaining power of the parties.

Under the new Act, strikes over issues which fall within the jurisdiction of disputes committees and personal grievances remain illegal, but the Labour Relations Act incorporates the right to strike over interest disputes. There are no prohibitions related to striking while disputes remain in conciliation council. Arbitration is no longer compulsory. The parties to a dispute of interest must agree to arbitration. The former responsibilities of the Arbitration Court have been divided between a new Labour Court and Arbitration Commission. The Arbitration Commission has the voluntary arbitration function in relation to disputes of interest. While consultation with the Commission is required, there are no prohibitions against striking while these consultation procedures are carried out. The Labour Court retains the interpretation and enforcement functions.

A criticism of the former system of compulsory arbitration is that awards were negotiated almost solely on the basis of intra-award relativities, and not on the basis of the industry's or company's capacity to pay. The term relativity has been used mainly to mean the historical relationship between key award rates. Bargainers tended to trace the mathematical relationship over past settlements between a key rate in one award and the key rate in a comparison award. The rates of registered electricians were related to indentured fitters, indentured fitters to indentured carpenters, indentured carpenters to labourers and clerical workers, labourers to drivers, and drivers to storepersons. The rationale of bargainers was either to pass on the going rate, or concentrate on a specific parity with a comparison award. In recent years the going rate has generally been the major feature with some attention being paid to macroeconomic argument during the initial pace setting award negotiations. But once precedence has been set, economic arguments have had little effect on the viability of outcomes in negotiations.

Compulsory arbitration was one aspect of the system which reinforced relativity. In contrast, the outcomes of collective bargaining within a deregulated industrial relations system are determined by bargaining power. If the Distribution Workers Union has the power to bring commerce to a halt, then drivers can look forward to a more positive outcome than can the local body officers. Under the compulsory arbitration system the Local Body Officers Union had direct access to the Arbitration Court, and either the Court historically enforced the going settlement rate, or employers conceded what they knew the Court would enforce.

The critical question raised by the Labour Relations Act is whether the bargainers will voluntarily continue to reflect in their settlements the overall sense that workers should be treated equally, at least in terms of the minimum requirements of awards, or whether the economic fortunes of the individual worker shall be determined solely on the basis of bargaining power. Signals as to the future behaviour of bargainers are mixed. In the last wage round, the first completed under the Act, two out of three settlements were reached between 7 and 8 percent. That statistic does not suggest that the Labour Relations Act has made any significant contribution to wage flexibility. The Metal Trades Award was initially settled at 7 percent, and the vast majority of awards simply followed on without regard to variations in the individual industries' capacity to pay, or the individual bargaining strength of unions.

As always there are different views on whether 7 percent was too little, or too much. One view was that 7 percent was too much. The economy has suffered more than the United States economy had suffered during the middle 1970s. Certainly, the recent announcement that unemployment has increased by 20 percent over the year ending March 1988 lends credence to this argument. Agreement between employers and unions exists that manufacturers are failing to compete on the domestic markets against the increasing cheap imports. The high dollar poses a barrier to exporters. These features were critical features of the United States economy when in the late 70's and early 80's a large number of United States labour negotiations ended in nil wage increases, or "give backs" by unions. There are alternative arguments that 7 percent may not have been excessive. 
However, given the crippled state of various sectors of the economy, the uniformity, if not magnitude, of settlements is astounding, particularly given the greater flexibility either suffered or enjoyed in markets other than the labour market. Against this, however, there were a small number of settlements which revealed a potential for greater wage flexibility.

As a part of the overall Metal Trades settlement the parties agreed that there would be a restructuring of the engineering industry negotiations. The structure of the General Metal Trades Award was derived from the amalgamation of a number of separate industry awards in the 1970s. The Metal Trades Award will be split back into sector awards. The prospect has also been put forward that these sector awards may be negotiated on a composite basis with other unions in the sectors joining in negotiations for a composite sector award. The idea presumably is to negotiate awards which are sensitive to the economic needs of individual industries. It should be pointed out however that this development is not because of the Labour Relations Act. Sector awards existed under the Industrial Relations Act prior to their amalgamation within the General Metal Trades Award. Provisions under composite negotiations also existed under that Act. Hence, the move has been at the initiative of the bargainers, not because of the requirements of the Act.

While there have been a limited number of composite agreements read under the old Act, the composite provisions did not succeed in encouraging widespread composite bargaining. It is also uncertain that other unions will take up the engineers lead and join in composite bargaining, or agree to sectorise their own awards. In contrast, the Hotel and Hospital Workers Unions sought to negotiate a New Zealand Health Services Award which required amalgamating three awards which applied in public hospitals, private hospitals, and rest homes. While the unions were not successful, significant improvements for rest home workers were gained, and the National Health Workers Award is likely to remain on the union's agenda during the next wage round. However, the objective will not be conceded easily by employers. Already private hospital employers have filed claims for a composite, private sector hospitals award citing both hospital workers and nurses. Evidently, employers see a composite award providing some solution to demarcation problems between orderlies and nurses.

If these industry sector initiatives do succeed, there may well be greater wage flexibility as the transport industry's settlement has revealed. The General Driver's Award has in the past brought together three major industry groups: general transport, contractors of heavy machinery in construction and ancillaries to employers of drivers in manufacturing and other industries where transport is not the principle objective. The perceived capacities to pay off these three industries have not always run in tandem, and award negotiations were then characterised by one or more sectors of employers refusing wage increases which the remainder found acceptable. Nevertheless, the wisdom until last year's negotiations was to keep the three sector award intact. This year negotiations broke down, and three individual sector awards were settled. The contractors settled first with an 8.6 percent increase plus a major adjustment to the industry allowance. The union insisted this represented approximately a 14 percent increase on average for drivers in the contracting industry. The transport award was then settled on the same basis. But negotiations over the ancillary award floundered. After protracted negotiations, part of the industry settled on 8.6 percent for wages and 8.6 percent for the industry allowance. Relativity was broken between the ancillaries and general transport and contracting with the exception of the Northern Industrial District. The Northern Drivers Union has refused to accept the settlement, and are pursuing the issue on a job to job basis.

Employers were willing to deal with the unions on an industry sector basis, and the industry sectors had clearly perceived differences in their capacity to pay or their ability to withstand industrial disruption. Drivers employed in the manufacturing sector, arguably the weakest sector, received less. In terms of industrial strength drivers are far weaker in the ancillary section. Small numbers of drivers are employed by a diversity of ancillary 
employers. These drivers are more difficult to organise, particularly in the manufacturing sector, and their employers are suffering under the present economic policies. Nevertheless, many drivers employed by ancillaries drive the same trucks and carry out substantially the same duties as drivers employed by transporters. The settlement illustrates a clear shift from the basis of settling the award on the principle of equity, to the principle of industrial power. Importantly to the rest of the wage round, the 14 percent settlement was not accepted as a precedent. Under the compulsory arbitration system with the Court as a back up, experience was that the precedent would have been followed throughout the remainder of the wage round. In fact the General Drivers Award was often placed early in the round because of the strategical advantages of the Drivers Union. The award was used as a precedent for the whole of the wage round. The drivers settlements may represent the first clear lesson about bargaining under the Labour Relations Act: unions with the power produce the results.

\section{The subject matter of collective bargaining}

The importance of union organisation and bargaining power is further reinforced by two alterations in the Act. Under the Industrial Relations Act the subject matter of bargaining was restricted by the definition of industrial matters. In contrast the Labour Relations Act does not define industrial matters. Similarly, the Industrial Relations Act restricted the objectives of registered unions, but under the Labour Relations Act no such restrictions exist. Unions with bargaining power will not only provide for better settlements over the traditional subjects of collective bargaining, but the range of subjects has been increased. That is particularly important as the welfare state continues to be dismantled. Clearly, superannuation is a critical item for the future bargaining agenda. Major alterations to National Superannuation appear to be inevitable regardless of which party is in power. While recent removal of tax incentives may initially discourage employer supported superannuation, the union movement will provide a fresh incentive. No doubt national negotiations will feature not only the power of industrial punches, but important philosophic debate as to whose responsibility the supplementation of superannuation should be. Similarly, with moves towards a greater reliance on private health care, employers will be asked to take responsibility for medical insurance. If North American patterns develop, then dental and legal insurance will also find their way to the bargaining agenda.

The irony of course is that the philosophers of the deregulated market, who have so strongly insisted that New Zealand society would improve if the individual took responsibility, are going to be among those who are asked to pay, and their valid objections will be on financial, rather than philosophic grounds. The collective claims of the union movement are no less a result of individual initiative and co-operation than are the corporate demands of a collection of shareholders organised into a limited liability company. Strong unions will insist that the employers assume the responsibilities shed by the state, and the end result of the privatisation of New Zealand for many employers will mean greater, not lesser labour costs.

A second alternative is where the employer refuses to take over the former responsibilities of the State, but these responsibilities are assumed by a strong union. There is no longer within our labour legislation any prohibition against unions running their own superannuation, health, dental, and legal schemes, or for that matter operating their own businesses, or making substantial support provisions to assist individual workers' participation in industrial warfare. Where the union assumes these responsibilities, the responsibilities will be funded from union dues. Under the Labour Relations Act there is no longer a limitation on what union dues may be required. Union dues are paid through wages, and wages in turn paid by employers who negotiate with powerful unions. The additional increment to cover the necessary increase in union dues 
will come out of the employers pocket. The unions' assumption of the former responsibilities of the State will cement the powerful loyalties of their membership. But in the final analysis it is the employer who will pay the price both in terms of the wage bill, and in loss of the worker's loyalty.

\section{Restructuring unions}

The third alternative, and a real alternative in many industries, is that a particular union will not have the bargaining power to succeed against employers. In a system whose results are generated purely by bargaining power, outcomes will become increasingly conspicuous. The union dues will be considered a worthy investment where the union delivers. Where the union fails in its delivery its membership will become increasingly frustrated, and in search of alternatives. One alternative is a competing and more powerful union. In practical terms the compulsory arbitration/unionism system granted in perpetuity exclusive bargaining rights for workers which fell within their jurisdiction as determined by their rules registered under the Act. According to the free marketeers this has calcified a union structure which has been rendered by force of law incapable of changing with the times. This provided stability for the union's structure, and eliminated conflict in the work place between competing unions, but did not allow unions to compete for one another's membership. Such competition is no longer prohibited.

Under the new legislation unions may compete for members, provided they follow a set of procedures. These procedures require that the union give notice to the Registrar of Industrial Unions, the central organisation of workers, and any unions affected by a proposed change in coverage. The notice is to be to the effect that within three months a union intends to apply to the Registrar of Unions for approval to include a new category or categories of workers within their union membership. Extension of the coverage is subject to two ballots. Firstly, the union must conduct a ballot of its own membership to determine if there is support to extend the coverage. If support is received, then the Registrar is to conduct a ballot of workers to be covered by the extended coverage. If the members of the initiating union and the workers to be newly covered support the extension of coverage, in both ballots, then the Registrar of Unions amends the membership rule of the union to effect an extension of coverage.

While these changes allow for competition between unions, the new Act does not provide for the ultimate competition between the union and employers. The new Act reenacts a system of compulsory unionism. This system allows the union to negotiate union preference provisions requiring all employees to join the union within 14 days of being requested to do so by the union. Failing agreement to a preference provision, the issue is to be determined by ballot carried out by the Registrar of Industrial Unions. The ballot is carried out over all employees in the industry. The history of this arrangement for preference provisions has been that industry-wide settlements have depended upon employers conceding the preference provision, and employers have almost universally conceded. A variant of this arrangement was enacted under the previous government prior to their voluntary unionism enactment. This required balloting to determine union members' views as to whether the union should seek preference provisions. Universally, majorities of workers supported preference provisions.

Under the compulsory arbitration/unionism system union members of different unions received a remarkably uniform reward for union membership. That may no longer be the case, and an increasing support for voluntary unionism amongst the membership of weaker unions is likely to result because these unions may be unable to deliver. Individual employers complain that the system does not allow them to compete for the hearts and minds of their own employees, and imposes a labour monopoly upon their industry. A sense of employee's genuine frustration with paying union dues to a union that cannot deliver may prompt employer negotiators to oppose the incorporation of a 
union membership requirement in the award. Voluntary unionism under the previous National Government was perceived by many employers as a brief but successful experiment. An election of the present opposition party will mean a return to voluntary unionism, and there are those who predict voluntary unionism to be the outcome of the present split between the political and industrial arms of the labour party. Voluntary unionism will mean that weaker unions may wither in some industries. But under a system where unions may compete for membership, there may be a genuine reformation of the union structure because workers will seek membership within effective unions. Workers will be attracted to powerful unions which can deliver in a country where workers can no longer depend on the state for the basic protections, and where the law no longer limits the subject matter of bargaining.

\section{Bargaining units and labour market flexibility}

The term "industrial" union under the old Industrial Relations Act was a misnomer. The Woollen Workers Union is not an industrial union but shares the woollen industry with a number of occupationally based unions. The Clerical Union was considered an industrial union, but in fact its membership is occupationally based and works in a wide range of industries from the automotive industry to the woollen industry. Similarly, the Building Trades Union is composed of various tradesmen, and is a multi-occupationally based union. Its membership is engaged in a range of industries. For example, a carpenter may be employed in general construction, or in the maintenance of a meat or wool processing plant. There is not a union for all workers in a single plant. A manufacturer may have 15 or 16 individual unions within his plant. Nor are there industry unions in the sense of a single union for a particular industry, like for example a United Autoworkers Union. A number of employer organisations have argued that plant, or industry-wide unions are bargaining partners which would allow for greater flexibility between companies and industries in the sense of accommodating the economic circumstances of the individual company or industry. However, the Labour Relations Act does nothing to change the present structure of the union movement from its occupational or multi-occupational basis, and in fact may promote a further development of the union on a basis which embraces an even greater diversity of occupations.

Under the previous Act the objectives of a registered union were to protect and further the interests of workers within a specific industry or related industries. The Act restricted registration to a single "industry" (occupation) with limited exceptions where the Governor-General could declare specific industries to be related to one another for the purposes of registration. There are no such restrictions under the new legislation. Strong unions will not be company or industry based, but will add to their present multioccupational structure a diversity of occupations. Allowing competition between unions does not address the problem of appropriate bargaining units. The reshaping of unions through competition, amalgamation, and federation or association, is likely to create unions who choose bargaining units no more susceptible to economic rationalisation than the bargaining units which are presently the subject of employer criticism.

In terms of wage flexibility derived from plant bargaining, the provisions of the Act actually provide a disincentive insofar as the union must be cautious in endeavouring to negotiate agreements with individual employers separate from the award. Under the new Act the union must make up its mind whether an industry-wide award shall have application to an employer, or to directly bargain with the employer over the terms and conditions to apply to the employers enterprise. Unlike the previous system where a contract of employment could be effected by both an award and a second-tier agreement pertaining to his individual employer, the contract of employment can be affected by only one collective agreement. An employer can be exempted from the award for the purpose of affecting an individual agreement in either of two ways. Firstly, the employer can be 
cited out of the award at the commencement of award proceedings. The award is then settled separately, and the union negotiates directly with the employer. The union has the right to strike over the award, and if the employer is cited out, the union retains the right to strike over the individual agreement.

The second way in which the union can negotiate a separate agreement is to approach the employer during the duration of the agreement. If the employer is willing, an agreement can be achieved. However if the employer resists, the union cannot legally strike. By endeavouring to negotiate after the award is settled the union gives up its bargaining power. By citing out the employer before an award settlement, the union retains bargaining power, but takes a specific risk. The union becomes committed to a truly deregulated labour market. Once cited out, the employer can refuse to negotiate. If the union cannot force the employer's capitulation, then no collective agreement applies to the employees. Further, the union cannot regain coverage under the award unless agreement is reached with the employer that his workers should be covered by the award. If no agreement applies, then the unqualified preference clause does not apply. Workers then have the full freedom to choose whether they wish to be or not to be a member of the union. The employer can effectively refuse to recognise the union as a bargaining agent. (The one exception would be that the Labour Relations Act establishes the right of the union to represent its membership in personal grievances even if they are not covered by an award or collective agreement.)

The new legislation does provide for composite negotiations where several unions may negotiate with a single employer, or industry. The Act is designed to encourage this type of bargaining in that bargaining on a composite basis does not exclude the unions from award coverage if their negotiations fail. However, these provisions existed under the previous system, and resulted only in a few composite agreements, notably in the motor assembly industry and on large, remote construction sites. If past history is an indication then nothing in the new legislation suggests a general move to composite bargaining within the individual work place, and there are disincentives for individual unions to negotiate with the individual employer.

The government has stated that its intentions are to strengthen the union movement so that it can survive what would be an even more hostile environment if the present opposition were to become government. The aim is to create larger and more effective unions. Under the new legislation unions will require a membership of at least 1000 to retain registration under the Act. This aspect of the legislation in fact removes the possibility of plant unions with the vast majority of small New Zealand employers employing less than 1000 workers. Plant or industry-wide unions do not appear on the government's agenda. If the union movement responds to the potentials created by the Act, the national award system may in the future be held together by the bargaining power of a smaller number of more powerful unions of a multi-occupational basis. But this change is likely to reinforce relativity rather than create greater wage flexibility. Occupationally based awards saddle different industries with varying capacities to pay. Negotiations tend to concentrate on comparisons of occupations because economic concerns differ significantly between industries, making the accommodation of any one industry difficult.

\section{Uniformity during the $87 / 88$ wage round?}

The compulsory arbitration system provided for the clear expression of what was once New Zealand egalitarian philosophy by imposing a remarkable uniformity in wages and conditions within the national award system. One would anticipate under free collective bargaining a greater variation in settlements than under compulsory arbitration. The uniformity of the last wage round is difficult to explain. Perhaps this relates to the cultural values of the bargainers, but the explanation is likely to be more concrete than the 
flagging spirit of our national egalitarianism. A more concrete explanation relates to the occupational basis of the awards. A labour relations manager for a large manufacturing plant may well act as a negotiator in several national award negotiations, and if not formally nominated as a negotiator on the conciliation council, the labour relations manager will be an observer and participate in employer deliberations over other key negotiations.

His company will have a similar union representation to other companies. Each manufacturer represented at the negotiations will have a number of national awards applying at their plant. National awards will be accommodated by at least three different arrangements. Firstly, some manufacturers will simply pay award rates. Secondly, some manufacturers will pay a set margin above award rates. Thirdly, some manufacturers will pay new employees the award rate, but increase rates of pay after a period when the worker proves satisfactory. Most pay structures within the industry will key off the award movements, but will have additional increments which reflect the labour market conditions in the area.

While employers may desire the flexibility to make adjustments that reflect the different circumstances between companies, the same flexibility for intra-company adjustments between different sets of workers is not as practical. Employees make clear and highly charged comparisons to other employees within their own company. Wage and salary systems endeavour to provide a rationale that employees view as fair. Job evaluation is generally weighted for equity considerations, whereas market forces determine rates on the basis of supply and demand, rather than skill, effort and responsibility. If a concession ensures the continuing viability of the company, workers might wear a 3 percent increase when a neighbouring company has granted 6. However, granting 6 percent to drivers and 3 percent to storepersons within the same company has serious implications for moral and in-plant industrial relations, and is likely to precipitate action by storeworkers to regain parity. Uniformity in national award settlements is therefore desirable from the in-plant wage and salary administration perspective. This is because the award settlements generally affect the base of the in-plant wage and salary administration structure of the individual company.

Negotiators will strongly resist claims in the ancillary drivers award which exceed those granted to storepersons. On the other hand employers may grant an increase to clerical workers which equates to the storeperson's increase, even when the clerical workers do not have sufficient bargaining powers to gain the general increase granted to storeworkers. The general emphasis in bargaining will not be towards variability, but to set a low and consistent general movement applying to key awards within the individual enterprise, and which affect the base of the in-plant or enterprise wage and salary structure. The simple reason for wage uniformity in the last wage round is that the employers do not desire wage flexibility within the award structure, and the balance of bargaining power is at present tipped in the employers direction. The flexibility that some employers want is an inter-company flexibility, and the new system neither provides for company unions nor requires occupationally based unions to bargain on a company basis.

\section{Future trends and wage flexibility}

If the deregulation of the labour relations system had been more complete, company or plant bargaining units could be arrived at because union recognition and the bargaining unit, itself, would be negotiable items. The bargaining power of the employer would be a determinant in deciding whether his company would be party to a plant, as opposed to an industry-wide, union. However, the Labour Relations Act is not designed to promote plant or company bargaining. Conciliation remains compulsory with unions registered under the Act, and therefore union recognition is not an item for bargaining. The employer might persuade the union to cite the company out of the award, but the 
employer does not have the right to refuse to be party to the award. Therefore the employer must both recognise the union for the purposes of bargaining, and be party to an industry-wide bargaining unit. According to a recent decision of the Labour Court, the employer does not have bargaining rights with respect to the type of bargaining unit even if his workers desire a separate agreement against the wishes of the union (Finnigan, D. in Meat Workers Union v Ventec Corp Ltd.). Nor can the workers break away from the union to form a plant union and thereby change the bargaining unit. Nor can the employees of a single employer decide they do not wish to be in the union. While union employment preference may be rejected, the vote is taken on an industry-wide basis, and not a company basis. The Act simply prohibits these types of adjustments. Unions have retained the power to cite all employers within an industry and to negotiate on an industry basis. These provisions of the Act encourage a continuation of occupationally based industry awards which give impetus to wage uniformity.

While wage uniformity has been the trend since the lifting of the wage freeze, there have been a few exceptions. In the Building Industry an industry allowance has been granted which represents an additional margin. The margin has been passed on to some awards which have application in the building industry, but the margin has not been reflected in other awards which have had traditional relationships to the Building Trades Award, but which do not apply to the building industry. The Building Trades Labourers have picked up the industry allowance, but the industry allowance has not followed on to the General Metal Trades Award where there has been a link between the carpenter and fitter. However, the allowance has been reflected in the Heating and Ventilating Award to which the Engineers Union is a party, and which applies to the building industry. Similarly, the allowance has been reflected in the Electrical Contractors Award, but not the Maintenance Electricians Award. Therefore, certain engineering and electrical tradesmen employed in the Building Industry have received additional increments pertaining to the Building Industry, whereas maintenance electricians and engineering tradesmen have not received the additional increment. Maintenance tradesmen have been constrained to accept the general increase determined by the ailing manufacturing sector.

Negotiating a series of awards applying to a single industry and not between industries might be a first step to composite bargaining which some employers view as a more positive commitment to wage flexibility. However, the extra movement in the multiple award arrangement has not been because the unions seek general wage mobility. Unions will not wish to attach themselves to a composite agreement which lags behind or provides for downward movements in wages and conditions.

Given that the occupational structure of unions is not altered by the Act, given that unions determine what bargaining units they enter into, and given that the economy is not buoyant, the short term prospects of a more highly flexible wage system are not encouraging. The pressure will continue to constrain initial settlements and to retain relativity by virtue of handing out the same percentage increase to each union without the power to effectively buck the system. The trade-off is likely to be the maintenance of the national award structure in exchange for modest increases in the overall structure. For the near future such a trade-off may well suit the economic plight of the country. In the medium term the balance of bargaining power will inevitably shift. Workers will be attracted to strong unions which can deliver, and the structure of the union movement will alter through competition between unions. In the long term a corresponding shift will subsequently evolve in the national award structure, but this change of award structure is unlikely to represent greater wage flexibility between companies. As long as occupationally based awards saddle employers and industries with varying economic fortunes, the collective bargaining system will not account for the capacity of the individual employer or industry to pay. 